\title{
Polypore survey of Finland 5. The genus Polyporus
}

\author{
TUOMO NIEMELÄ and HEIKKI KOTIRANTA
}

\begin{abstract}
NIEMELÄ, T. \& KOTIRANTA, H. 1991: Polypore survey of Finland 5. The genus Polyporus. - Karstenia 31:55-68.

Distribution maps are presented for nine Polyporus species occurring in Finland. The commonest are $P$. brumalis (Pers.: Fr.) Fr. and $P$. ciliatus Fr.: Fr. A strictly southern species is $P$. badius (Pers.) Schw., which has been found in two places only, and to a lesser extent $P$. umbellatus (Pers.: Fr.) Fr.; both of these are classified as threatened. A widespread species with a southern emphasis is $P$. melanopus (Pers.: Fr.) Fr., from which $P$. tubaeformis Karst. has been separated. P. pseudobetulinus (Pil.) Thorn, Kotiranta \& Niemelä (syn. Piptoporus p.) has two localities in Finland and is considered to be threatened. $P$. squamosus (Huds.: Fr.) Fr. is sparsely distributed over the whole country and has two ecotypes, one growing on large park trees in old towns in the south, and the other a dwarfed kind inhabiting riparian thickets and having a northerly distribution. $P$. leptocephalus (Jacq.: Fr.) Fr. ( $P$. varius (Pers.: Fr.) Fr.) has a similar dual ecology, occurring both on dead, old-forest aspen trunks and on living park trees of various genera. All the species cause a white-rot, and, except for some questionable records from conifers, grow exclusively on hardwoods. Only $P$. squamosus does significant harm as a pathogen, causing decay in park trees.
\end{abstract}

Key words: Apyllophorales, distribution, Finland, fungi, mapping, Polyporus

Tuomo Niemelä, Botanical Museum, University of Helsinki, Unioninkatu 44, SF-00170 Helsinki, Finland

Heikki Kotiranta, Water and Environment Research Office (Nature Conservation), Water and Environment Research Institute, P.O.Box 250, SF-00101 Helsinki, Finland

In this paper the species of Polyporus sensu stricto in Finland are mapped as a continuation of our survey project (Niemelä 1982, Niemelä \& Kotiranta 1982, 1983, 1986). The records are based on herbarium specimens in H, HFR, JOE (University of Joensuu), KUO, OULU, and TUR.

Some taxonomical solutions should be indicated. Polyporus pseudobetulinus (Pil.) Thorn, Kotiranta \& Niemelä (1990) is included in Polyporus, instead of Piptoporus; it accords with the present genus in producing white-rot in wood. $P$. tubaeformis Karst. is separated from $P$. melanopus (Pers.: Fr.) Fr. on its differences in macroscopy and microscopy. $P$. leptocephalus (Jacq.: Fr.) Fr. must replace the familiar name $P$. varius (Pers.: Fr.) Fr., according to the new Code (Greuter et al. 1988), as indicated by Dunger (1987) and Krieglsteiner \& Krieglsteiner (1989).

No distribution maps of Polyporus covering the whole of Europe have been available during our prep- aration of this survey, and we are looking forward to the forthcoming book on European polypores by R.L. Gilbertson and L. Ryvarden. Maps of Ryvarden (1969) from Norway have served as the most important comparative source. In Sweden only sketchy maps by Ryman and Holmåsen (1984) cover the whole country, but Strid (1975) presented more detailed distributions of the species in northern Central Sweden. Several country and regional maps have been published from Central Europe. Accurate ones from western Germany are those by Plank (1978) and Krieglsteiner \& Krieglsteiner (1989), and from eastern Germany by Dunger (1987). A most noteworthy atlas of polypores in Czechoslovakia by Kotlaba (1984) includes 11 species of the genus, and allows an interesting comparison of our results with the records from the Temperate (Nemoral) vegetational zone. 
Polyporus badius (Pers.) Schw.

\begin{tabular}{lcc}
\hline Host & Whole of Finland & $\mathrm{U}$ \\
\hline Acer platanoides & + & + \\
Alnus glutinosa & + & + \\
Specimens examined & 2 & 2 \\
\hline
\end{tabular}

There are only two records of this rare species from Finland, both made in the Hemiboreal zone. The better known occurrence (Erkkilä \& Niemelä 1986) is in the University Botanical Garden in downtown Helsinki, amidst a park lawn, on a stump of Acer platanoides. The fungus fruited richly in 1985, 1986 and 1987, and more scanty fruiting has lasted until 1990. A specimen from the other locality (U. Kirkkonummi, Porkkalanniemi, 8.X.1964 V. Kujala \& L. Laine; HFR 8250) was found in a herbarium and no further data are available for it.

$P$. badius is a southern, Hemiboreal to Temperate species throughout the Nordic countries (Denmark: Knudsen 1982), being classified as threatened in Finland, and in Denmark and Sweden as well (Knudsen \& Vesterholt 1990). It is often widespread, albeit

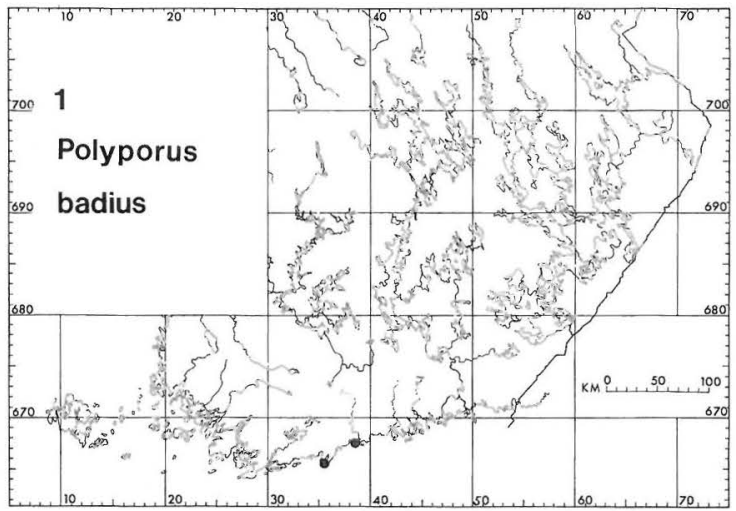

Fig. 1. Polyporus badius (Pers.) Schw. in Finland.

rare, in old beech forests in Central Europe, but the occurrence has long been difficult to estimate due to taxonomical and nomenclatural confusion. The best diagnostic character, simple-septate generative hyphae, is very difficult to discern in old fruit bodies. However, it is strikingly clear in the youngest growing pilei, in which the structure is still monomitic throughout, as is characteristic for the genus.

Polyporus brumalis (Pers.: Fr.) Fr.

\begin{tabular}{|c|c|c|c|c|c|}
\hline Host & Whole of Finland & $A-U$ & EK-PK & KP-PP & Ks-InL \\
\hline Betula spp. & 55.4 & 44.3 & 50.3 & 64.3 & 86.8 \\
\hline - pubescens & 3.4 & & & & \\
\hline - pub. ssp. czerep. & 2.6 & & & & \\
\hline - pendula & 1.0 & & & & \\
\hline Sorbus aucuparia & 14.4 & 21.4 & 15.8 & 7.1 & 2.9 \\
\hline Alnus spp. & 12.9 & 16.4 & 15.8 & 14.3 & - \\
\hline - incana & 5.4 & & & & \\
\hline - glutinosa & 2.8 & & & & \\
\hline Salix spp. & 7.2 & 3.6 & 15.0 & 4.8 & + \\
\hline - caprea & 4.9 & & & & \\
\hline - myrsinifolia & + & & & & \\
\hline Populus tremula & 4.1 & 3.6 & 2.2 & 7.1 & 7.3 \\
\hline Corylus avellana & 2.0 & 2.9 & 3.0 & - & - \\
\hline Prunus spp. & 2.0 & 4.3 & + & - & + \\
\hline - padus & 1.8 & & & & \\
\hline - domestica & + & & & & \\
\hline Quercus robur & 0.8 & 2.1 & - & - & - \\
\hline Acer platanoides & 0.5 & 1.4 & - & - & - \\
\hline Pinus sylvestris & + & - & + & - & - \\
\hline Rubus idaeus & + & - & - & + & - \\
\hline Host not indicated & 194 & 68 & 67 & 22 & 37 \\
\hline Specimens examined & 581 & 208 & 204 & 64 & 105 \\
\hline
\end{tabular}


$P$. brumalis seems to grow exclusively on indigenous trees in Finland. Its favourite host family is Betulaceae, especially the common genera Betula and Alnus. Rosaceae is also well represented among the host trees, in particular the genus Sorbus. The low proportion of the Salicaceae is surprising, as the ecology of willows should fit well for the fungus. The record from Pinus could not be confirmed. The proportion of records on birches rises considerably towards the north. Sorbus aucuparia is an important host in the south only, although the distribution of that tree covers the whole country.

The species is very common throughout Finland. It may be slightly more readily observed in Lapland, though the map does not reveal that tendency. Numerous herbarium specimens in southern and Central Finland reflect the fact that this stipitate polypore is often observed by mushroom collectors, too.

$P$. brumalis is hemerophilous, and its favourite growth sites are thickets bordering fields and roads, especially when coppice has been cut down and left in situ to decay. The fungus appears on this kind of wood 2-3 years after cutting. P. brumalis is also common on rock outcrops and it may be an important component of wood debris degradation in dry sites. In Lapland it occurs in natural stands of Betula pubescens ssp. czerepanovii ("ssp. tortuosa") at the timberline of the fjelds. Ryvarden (1971) has collected this fungus in Finnmark, northernmost Norway, on Betula. The species was recently reported from Greenland on Betula pubescens (Elborne \& Knudsen 1990) and it is also reported from Iceland (Hallgrímsson 1966). It seems to demand temporary high temperature, although the fruit body formation is known to continue in cold autumn weather. The thermophily makes it grow often in open sites together with Pycnoporus cinnabarinus (Jacq.: Fr.) Karst.

Fruit body growth starts in the south (A-U) in July, and further north in August. The peak of the growth is reached late in the season: in the south in October, in Central Finland in September, and growth is stopped by the coming of winter and permanent snow in September-October. In mild winters in the south the growth continues until March. All collections made in spring and early summer have been of overwintered, dead fruit bodies. The springtime peak in the diagrams of Ryvarden (1969) and Krieglsteiner \& Krieglsteiner (1989) may mostly indicate dead fruit bodies, but Jahn (1979) recorded new fruiting in Central Europe on March-April, too.

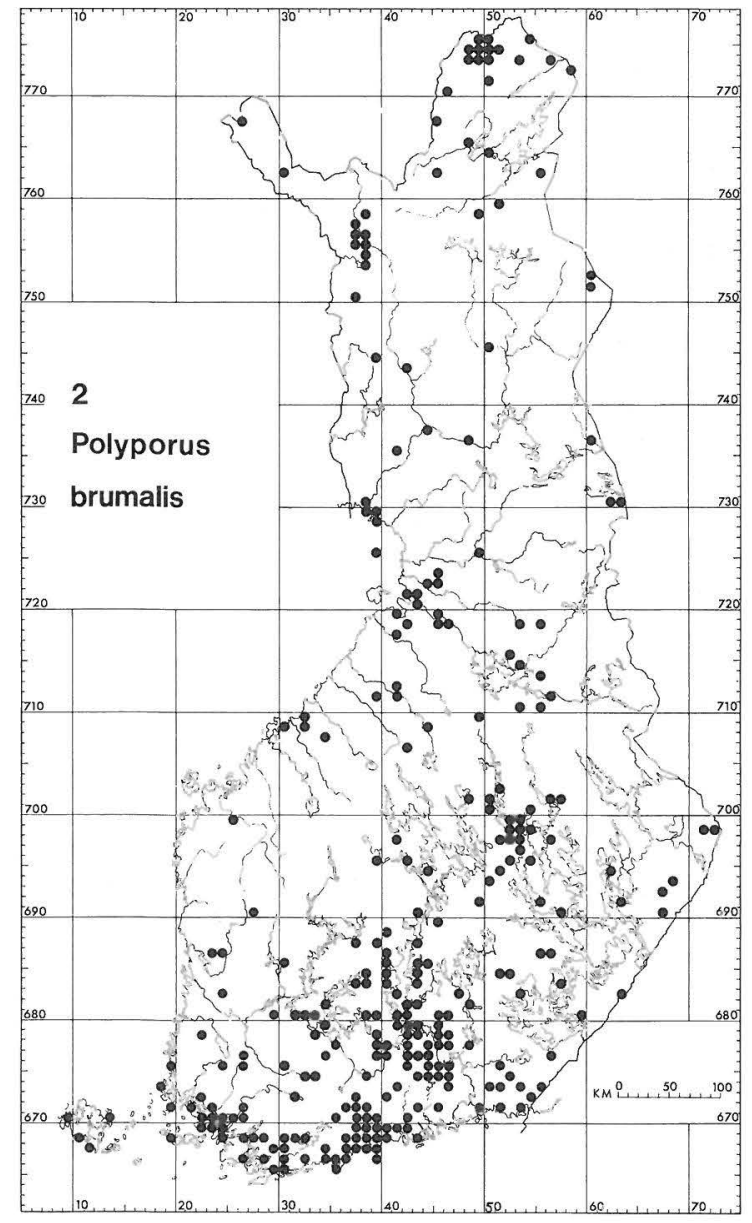

Fig. 2. Polyporus brumalis (Pers.: Fr.) Fr. in Finland.

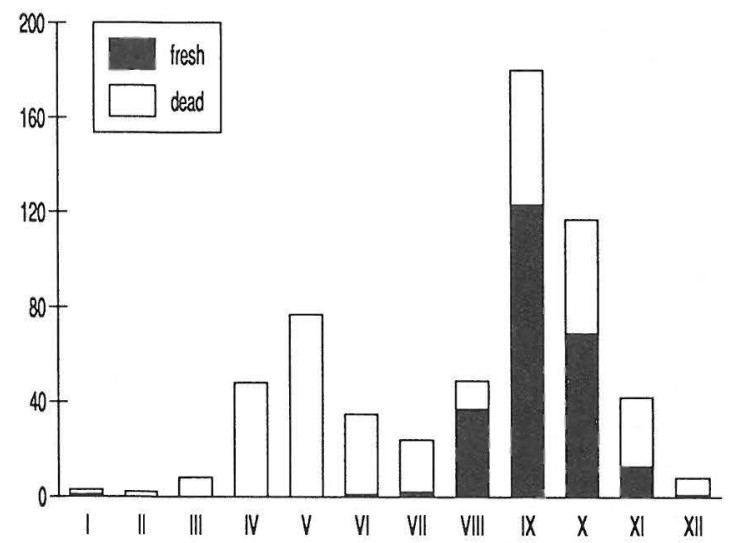

Fig. 3. Monthly distribution of collections of Polyporus brumalis (Pers.: Fr.) Fr. Black sections in the columns refer to specimens collected in fresh condition, white sections represent dead fruit bodies. 
Polyporus ciliatus Fr.: Fr.

Polyporus lepideus Fr.

\begin{tabular}{|c|c|c|c|c|c|}
\hline Host & Whole of Finland & $\mathrm{A}-\mathrm{U}$ & EK-PK & KP-PP & Ks-InL \\
\hline Betula spp. & 53.0 & 38.7 & 57.7 & 68.4 & 70.6 \\
\hline - pubescens & 3.4 & & & & \\
\hline - pub. ssp. czerep. & 0.6 & & & & \\
\hline - pendula & 1.5 & & & & \\
\hline Alnus spp. & 18.7 & 18.0 & 22.6 & 10.5 & + \\
\hline - incana & 7.4 & & & & \\
\hline - glutinosa & 3.7 & & & & \\
\hline Sorbus spp. & 10.1 & 17.1 & 6.9 & 7.9 & - \\
\hline - aucuparia & 9.8 & & & & \\
\hline - hybrida & + & & & & \\
\hline Populus spp. & 7.4 & 9.0 & 5.7 & 7.9 & 11.7 \\
\hline Salix spp. & 4.0 & 4.5 & 3.8 & - & - \\
\hline - caprea & 1.8 & & & & \\
\hline - phylicifolia & + & & & & \\
\hline Prunus spp. & 2.8 & 6.3 & + & + & - \\
\hline - padus & 1.2 & & & & \\
\hline - domestica & 0.9 & & & & \\
\hline - cerasus & 0.6 & & & & \\
\hline Corylus avellana & 2.5 & 6.3 & + & - & - \\
\hline Malus domestica & 0.6 & - & + & + & - \\
\hline Pinus sylvestris & + & - & + & - & - \\
\hline Rhamnus frangula & + & + & - & - & - \\
\hline Tilia cordata & + & - & + & - & - \\
\hline Host not indicated & 273 & 120 & 115 & 33 & 5 \\
\hline Specimens examined & 598 & 231 & 274 & 71 & 22 \\
\hline
\end{tabular}

The host tree preferences of $P$. ciliatus closely resemble those of $P$. brumalis. Birches are the main hosts and their proportion increases northwards. Sorbus aucuparia, which came second among the hosts favoured by $P$. brumalis, is replaced by Alnus species for $P$. ciliatus. This may be explained by the fact that $P$. ciliatus occurs less frequently on rock outcrops and more often in moist scrub on lakesides and field margins. In the wide selection of indigenous hosts the record on Pinus is anomalous; unfortunately it could not be verified. Ryvarden (1978) refers to a collection from Juniperus in Sweden.

$P$. ciliatus is very common in South and Central Finland, where its frequency is comparable to that of $P$. brumalis. These are the two commonest species of the genus. In the north $P$. ciliatus is the less abundant of the two, perhaps because of the more open character of broad-leaved tree stands there. Springtime collecting of fungi is fairly restricted in the north, which may also decrease the records there. However, Ryvarden (1971) has found the species in northernmost coastal Norway on Alnus.
In spite of the slight preference of more shady, moist sites, the ecology of the species resembles that of $P$. brumalis. Cut-down coppices and fallen twigs are especially suitable for $P$. ciliatus, although it sometimes grows on log-sized, cut trunks of birches, too.

$P$. ciliatus is an early fungus: in most of Finland the first fruit bodies emerge in May. Fruiting decreases drastically during July, and in August very few living pilei can be found. Jahn (1979) recorded a second, smaller fruiting peak in July-August, but this could not be found in our material. The fruit bodies decay soon after their death.

The taxonomy of this polypore has been unsettled for a long time, due to the very variable fruit body characters (degree of hirsuteness of the cap, fleshiness of the fruit bodies, structure of the stipe surface trichoderm). Two species or subspecies, $P$. ciliatus and $P$. lepideus (Jahn 1979, Jülich 1984), are sometimes separated. However, Esser and Hoffman (1977) demonstarted by interfertility tests that the two taxa are conspecific and most of the variability is due 


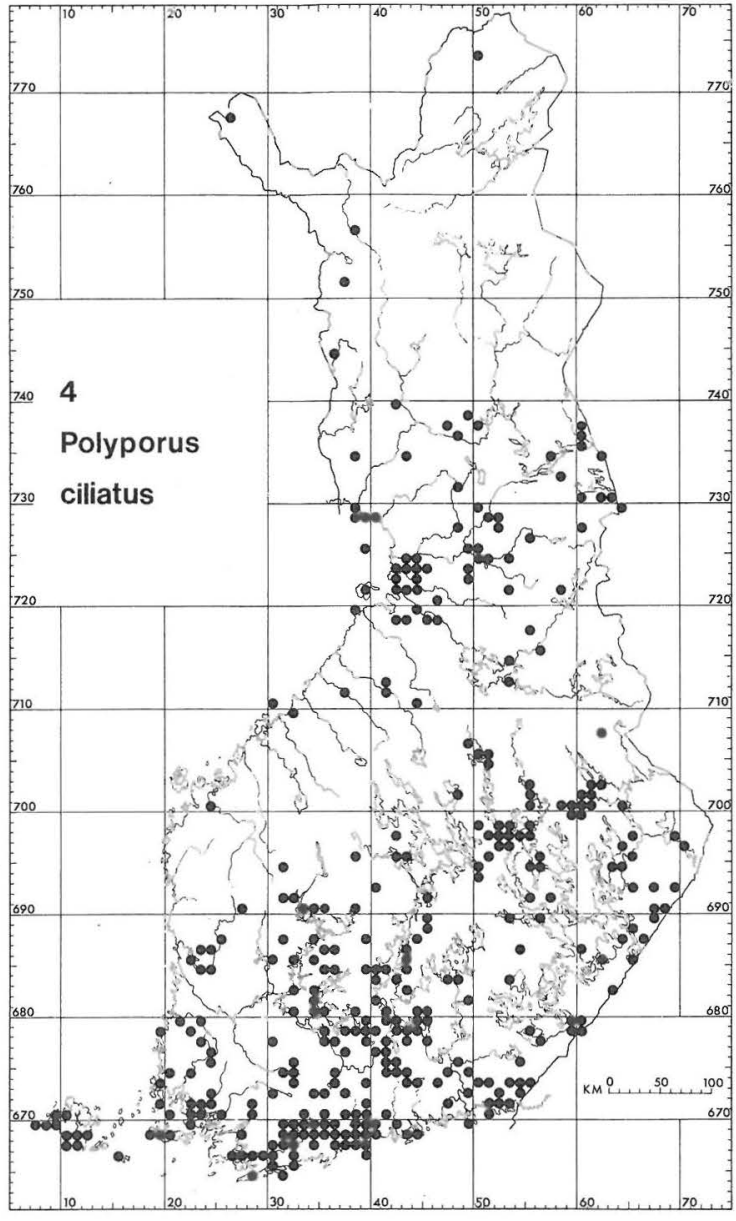

Polyporus leptocephalus (Jacq.: Fr.) Fr. Polyporus varius Pers.: Fr.

\section{(See overleaf for host list)}

The distribution covers the whole country. P. leptocephalus occurs fairly regularly in suitable habitats, but is never abundant. Within this wide total range, it shows a dual ecology in a somewhat similar way to that of $P$. squamosus.

An "old-forest ecotype" of $P$. leptocephalus is a saprophytic inhabitant of natural, old, mesic forests, preferably in a virgin state. Well-grown spruces predominate in the sites, intermixed with large aspen trees. P. leptocephalus fruits on fallen trunks of aspen, which are often already covered by epiphytic mosses. The fruit bodies of this ecotype are fairly thin and fan-shaped, and elegantly slender, even nummular pilei can be found on thinner branches of crowns, on other woody debris, and on willows in

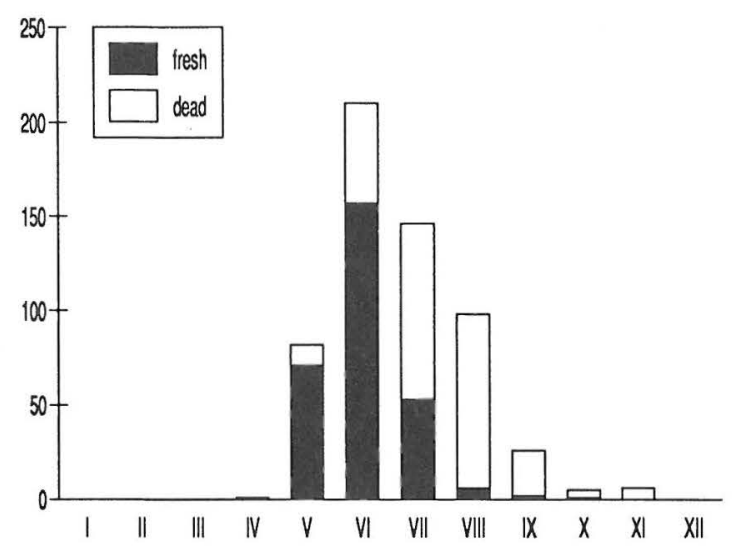

Fig. 5. Monthly distribution of collections of Polyporus ciliatus Fr.: Fr. in Finland.

to the atmospheric moisture in the environment. Accordingly, no separation of different fruit body types was made in this study.

Fig. 4 (Left). Polyporus ciliatus Fr.: Fr. in Finland.

northernmost Finland. Ryvarden's (1971) record of the species from northernmost coastal Norway on Salix evidently refers to a similar case. Although this "old-forest ecotype" has a northern emphasis, it is also encountered in the best forests of a late successional stage in South Finland. It was frequently found in moist thickets of Salix planifolia close to the timberline in northern Canada (Niemelä 1985). P. leptocephalus occurs in Iceland (Hallgrímsson 1966) and in Greenland it is occasional on Betula pubescens and Alnus crispa, and is even common on Salix species (Elborne \& Knudsen 1990).

In contrast to its old-forest relative, the "park ecotype" of $P$. leptocephalus is mostly parasitic. The commonest hosts are large, living Fraxinus, Tilia and Acer trees, where the fungus grows on large scars left when thick branches have been cut away or broken off naturally. The "park ecotype" of $P$. leptocephalus has 


\begin{tabular}{|c|c|c|c|c|c|}
\hline Host & Whole of Finland & A-U & EK-PK & KP-PP & Ks-InL \\
\hline Populus tremula & 26.6 & 7.7 & 31.5 & 65.8 & 23.3 \\
\hline Salix spp. & 23.1 & 6.6 & 29.6 & 24.4 & 58.1 \\
\hline - caprea & 11.4 & & & & \\
\hline - myrsinifolia & 2.6 & & & & \\
\hline - phylicifolia & 2.1 & & & & \\
\hline$-a l b a$ & + & & & & \\
\hline - alba X fragilis & + & & & & \\
\hline - pentandra & + & & & & \\
\hline Fraxinus excelsior & 10.5 & 24.2 & 3.7 & - & - \\
\hline Tilia spp. & 10.0 & 23.0 & 3.7 & - & - \\
\hline - cordata & 9.6 & & & & \\
\hline - platyphylla & + & & & & \\
\hline Betula spp. & 8.3 & 6.6 & 7.4 & 7.3 & 13.9 \\
\hline - pendula & + & & & & \\
\hline Acer platanoides & 3.5 & 8.8 & - & - & - \\
\hline Prunus spp. & 2.6 & + & 9.3 & - & - \\
\hline - cerasus & 1.3 & & & & \\
\hline - padus & 1.3 & & & & \\
\hline Alnus spp. & 2.2 & 3.3 & 3.7 & - & - \\
\hline - incana & 1.7 & & & & \\
\hline - glutinosa & + & & & & \\
\hline Malus spp. & 2.2 & 4.3 & + & - & - \\
\hline - domestica & + & & & & \\
\hline Ulmus spp. & 2.2 & & & & \\
\hline - glabra & 1.0 & & & & \\
\hline Picea abies & 1.0 & 2.2 & - & - & + \\
\hline Pyrus communis & 1.0 & + & 3.7 & - & - \\
\hline Quercus robur & 1.0 & 3.3 & - & - & - \\
\hline Corylus avellana & + & + & - & - & - \\
\hline Pinus sylvestris & + & - & - & - & + \\
\hline Ribes rubrum coll. & + & - & + & - & - \\
\hline Rubus idaeus & + & - & - & + & - \\
\hline Sambucus racemosa & + & - & + & - & - \\
\hline Sorbus aucuparia & + & + & - & - & - \\
\hline Host not indicated & 76 & 26 & 27 & 7 & 16 \\
\hline Specimens examined & 305 & 117 & 81 & 48 & 59 \\
\hline
\end{tabular}

tongue-like, fairly thick fruit bodies. The distribution is primarily southern, and most records derive from the Hemiboreal zone and southern half of the Southern Boreal zone. The low proportion of Populus tremula as a host in southern Finland reflects this dual ecology.

Scattered records exist of a wide range of host tree species; among them the solitary mention of Pinus sylvestris requires confirmation.

The two types of $P$. leptocephalus are similar in their phenology. The first fruit bodies appear in southern Finland in the second half of June, in the north in the first half of July. Live pilei can still be found at the onset of October (south) or until late August to mid-
September (north). Dead fruit bodies are very persistent. Overwintered, bleached caps of the "old-forest ecotype" stay identifiable until September-November, and make up a noteworthy part of the white sections of the columns in Fig. 7. The thicker and more fleshy fruit bodies of the park variety soon become rotten and disappear, or their remnants are stained blackish by Cladosporium sp. or other moulds.

The "old-forest ecotype" of $P$. leptocephalus is a useful indicator species in estimating the value of primeval forest areas for conservational purposes. As a pathogen the "park ecotype" may be of minor significance in causing decay in park trees. 

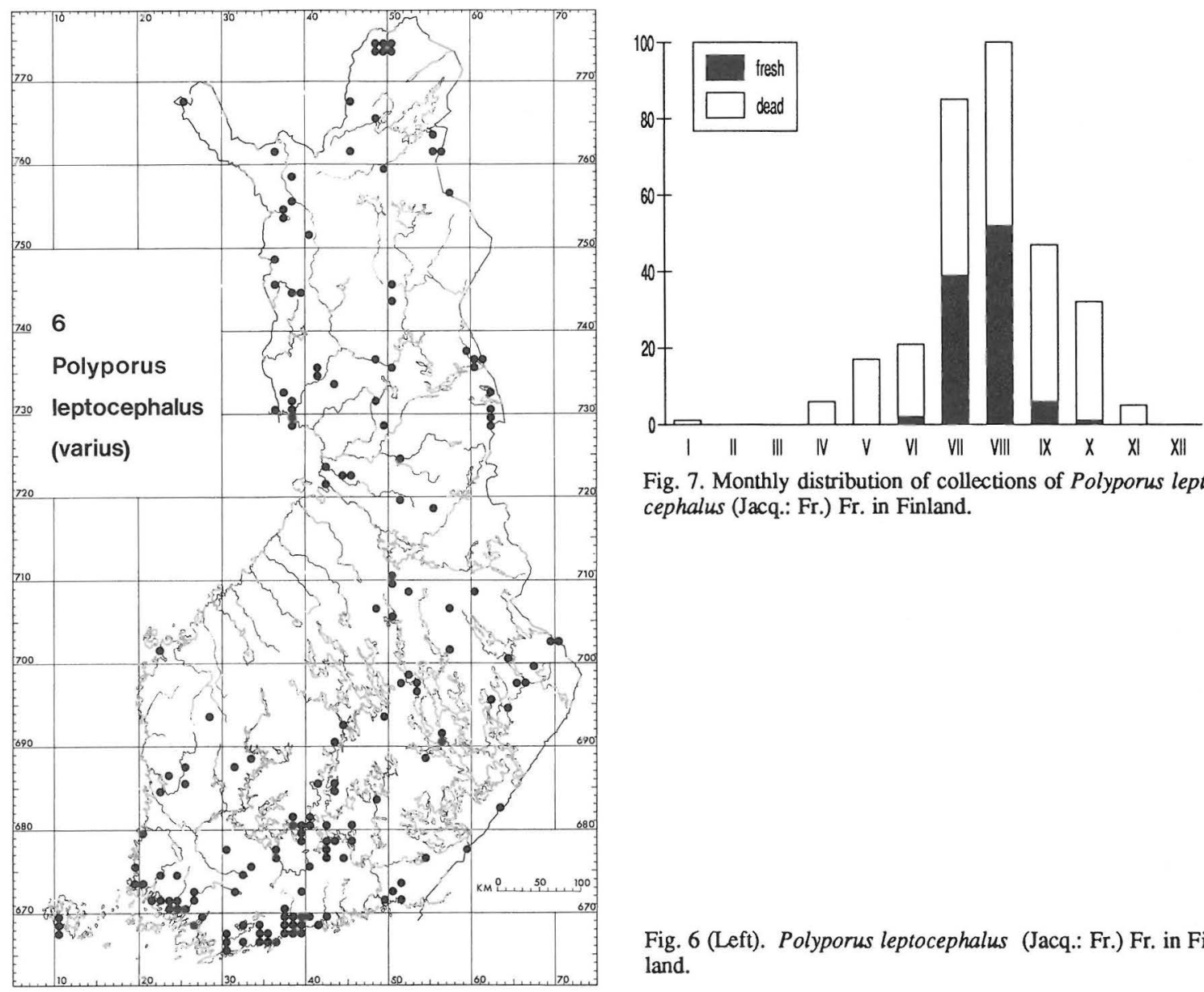

Fig. 7. Monthly distribution of collections of Polyporus leptocephalus (Jacq.: Fr.) Fr. in Finland.

Fig. 6 (Left). Polyporus leptocephalus (Jacq.: Fr.) Fr. in Finland.

Polyporus melanopus (Pers.: Fr.) Fr.

\begin{tabular}{lrrrrr}
\hline Host & Whole of Finland & A-U & EK-PK & KP-PP & Ks-InL \\
\hline Betula spp. & 56.7 & 27.3 & 73.9 & + & - \\
- pubescens & 8.1 & + & & & \\
- pendula & 29.7 & 45.5 & 13.0 & + & \\
Alnus spp. & + & + & - & - & + \\
Acer platanoides 'Schwedleri' & + & + & - & - & - \\
Corylus avellana & + & + & - & - & - \\
Picea abies & + & - & + & - & - \\
Sorbus aucuparia & + & - & + & - & - \\
Tilia cordata & 249 & 109 & 119 & 18 & 3 \\
Host not indicated & 286 & 120 & 142 & 20 & 4 \\
Specimens examined & & & & \\
\hline
\end{tabular}




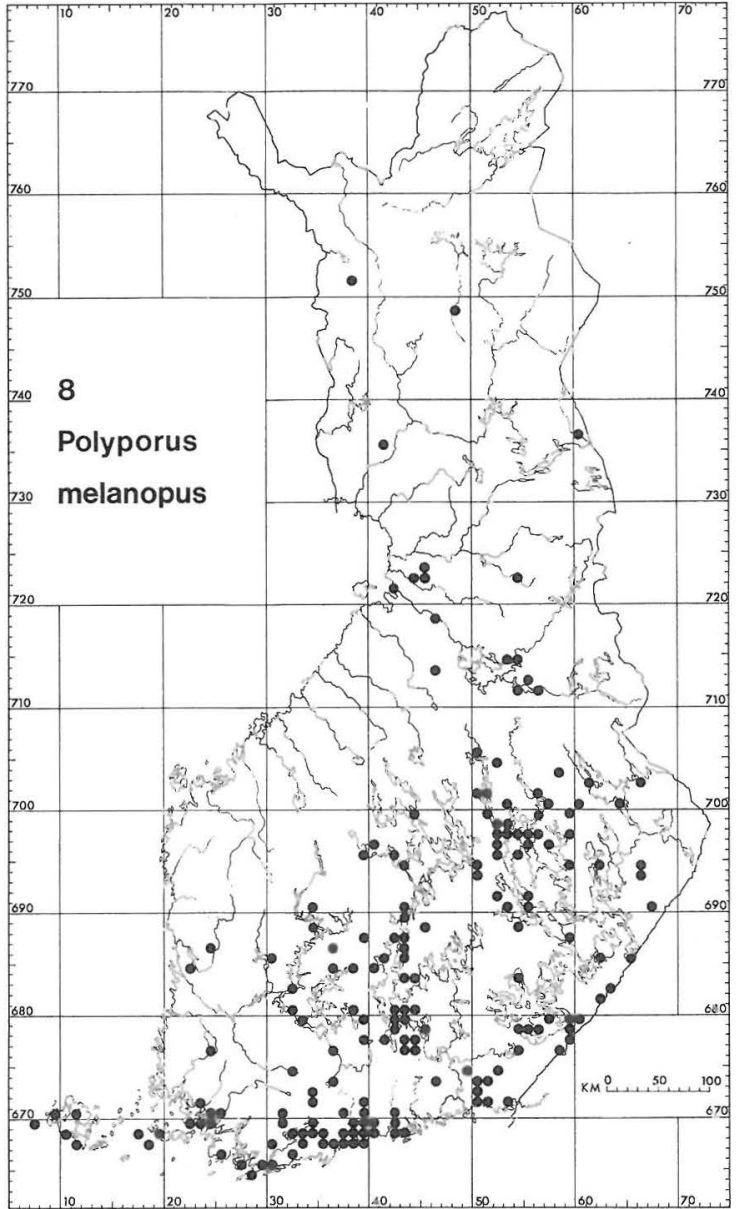

Fig. 8. Polyporus melanopus (Pers.: Fr.) Fr. in Finland.

$P$. melanopus is mostly associated with birches, and Betula is an almost exclusive host genus along the northern limit of the fungus. The emergence of fruit bodies from buried tree roots, apparently from soil, often makes exact host identification difficult, which is reflected in the great proportion of unidentified hosts in our table. Alnus seems to be another important host in southern Finland, but other woody species play a negligible role.

The species is evidently a pure saprophyte, whose fruit bodies arise from underground roots of stumps or dead trees. A few finds derive from exposed wood of stumps or stump roots.

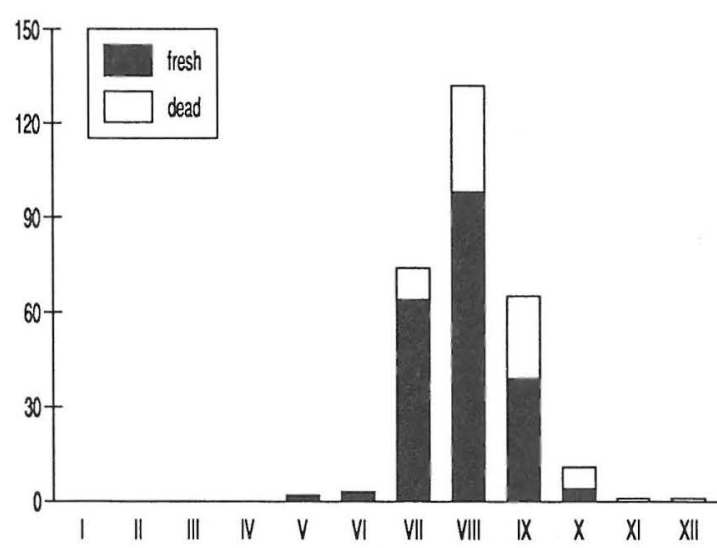

Fig. 9. Monthly distribution of collections of Polyporus melanopus (Pers.: Fr.) Fr. in Finland.

$P$. melanopus is frequent in the Hemiboreal and Southern Boreal zones, but is nowhere abundant. It seems to be very rare or nonexistent in the poor watersheds of western South Finland, and in the North. The maps of Hagström (1971) from Sweden and Ryvarden (1969) from Norway also reveal a wide total distribution but a southern emphasis, although both maps include $P$. tubaeformis. The species is classified as vulnerable in Denmark (Knudsen \& Vesterholt 1990).

This is a hemerophilous fungus of rich sites, preferably well-illuminated, grassy, sparsely wooded pasture land, and it seems to be favoured by the presence of robust stumps and perhaps elevated levels of nitrogen. In this respect its ecological preferences are similar to those of Ganoderma lipsiense (Batsch) Atk., with which it is often found together. Grassy field margins and even park lawns also suit $P$. melanopus well.

The species is a long-living saprophyte, whose fruit bodies appear in the same places year after year. They usually emerge from midsummer onwards, and very few caps can be found after the first half of September. After sporulating, the fruit bodies disintegrate and very soon disappear, which is in strong contrast to the behaviour of $P$. tubaeformis, with which it has the closest affinity. The fruit bodies in the herbaria are favoured by some insects, and unprotected collections are often eaten up, so that only thin surface layers of the fruit body caps and stipes are left. 
Polyporus pseudobetulinus (Pil.) Thorn, Kotiranta \& Niemelä

Piptoporus pseudobetulinus (Pil.) Pil.

\begin{tabular}{lccr}
\hline Host & Whole of Finland & PH & PP \\
\hline Populus tremula & 100 & + & 100 \\
Specimens examined & 19 & 1 & 18 \\
\hline
\end{tabular}

$P$.pseudobetulinus has been found in only two localities in Finland, and it is a threatened species (Rassi et al. 1986, Rassi \& Väisänen 1987) of the highest rank. Only one collection derives from the southern find, from the year 1956. The northern locality was first detected in 1957 (Thorn et al. 1990) and next in 1962 (Eriksson \& Strid 1969). The fungus was rediscovered there by T. Niemelä and H. Kotiranta in 1979 and since then Kotiranta has studied the population almost annually.

An extensive summary of the species records was published by Thorn et al. (1990); in it the species was reported as new to Sweden and Canada, and it was transferred from the genus Piptoporus to Polyporus on the basis of the decay and other characters.

In the following some more detailed notes are given on the ecology of the existing Finnish population, as observed by H. Kotiranta: The only known growth site at present is in the Pisavaara Strict Nature Reserve, on the boundary of Rovaniemi rural commune and Tervola about $30 \mathrm{~km}$ south of the Arctic circle. The nature reserve consists of old spruce ( $P i$ cea abies ssp. obovata) and pine (Pinus sylvestris) forests intermixed with birches (Betula spp.), Salix caprea and aspen trees (Populus tremula). The forests lie 80-260 metres above sea level. In the driest parts pine is dominant and the vegetation is poor, but the east-facing slopes partly bear very luxuriant virgin spruce forests. The most prominent vascular plants in the vicinity of the growth sites of $P$.pseudobetulinus are Actaea erythrocarpa, A. spicata, Athyrium filixfemina, Cicerbita alpina, Cirsium helenioides, Crepis paludosa and Daphne mezereum.

The aspens which are infested by $P$. pseudobetulinus are old (70-80 years), living, dying or dead. In the living host trees, the crown or large branches are typically dead, the bark is cracked and partly loosened or has even fallen off in large plates.

Polyporus squamosus (Huds.: Fr.) Fr.

\section{(See overleaf for host list)}

The distribution of $P$. squamosus covers the whole of Finland, but it is patchy. The species is generally

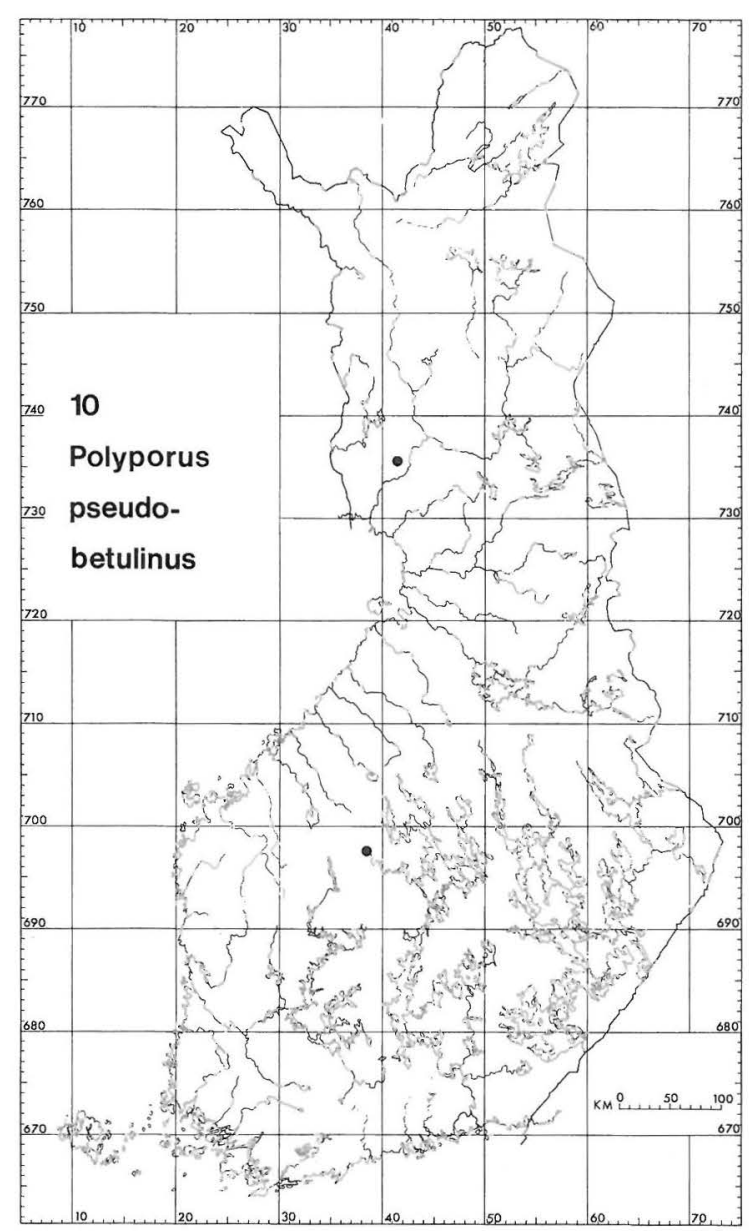

Fig 10. Polyporus pseudobetulinus (Pil.) Thorn, Kotiranta \& Niemelă in Finland.

In the relatively small area where the fungus lives, 11 trees with $P$. pseudobetulinus have been found. The height of the trees is mostly less than 20 metres $(12-21 \mathrm{~m})$ and the girth at breast height about $1.6 \mathrm{~m}$ $(0.7-2.1 \mathrm{~m})$. The fruit bodies were growing on the trunks about $5.1 \mathrm{~m}(0.5-12 \mathrm{~m})$ above the ground, and mostly emerged on the more sunny south-southeastern side of the trunk. P. pseudobetulinus does not fruit every year, but the fruiting can continue on the same trunk for more than ten years, and can also persist on a fallen trunk.

very rare, but in a few areas of southern Finland it is common or even very common. 


\begin{tabular}{|c|c|c|c|c|c|}
\hline Host & Whole of Finland & A-U & EK-PK & KP-PP & Ks-InL \\
\hline Salix spp. & 48.7 & 6.2 & 80.8 & 92.8 & 100 \\
\hline - caprea & 13.7 & & & & \\
\hline - myrsinifolia & 12.5 & & & & \\
\hline - phylicifolia & 3.7 & & & & \\
\hline - aurita $\times$ cinerea & + & & & & \\
\hline - fragilis & + & & & & \\
\hline - pentandra & + & & & & \\
\hline Ulmus spp. & 30.0 & 47.9 & + & - & - \\
\hline - glabra & 2.5 & & & & \\
\hline - glabra 'Exoniensis' & + & & & & \\
\hline Fraxinus excelsior & 11.2 & 16.7 & + & - & - \\
\hline Acer spp. & 10.0 & 16.7 & - & - & - \\
\hline - negundo & + & & & & \\
\hline Betula spp. & 3.7 & + & 7.7 & - & - \\
\hline Tilia cordata & 1.8 & 3.1 & - & - & - \\
\hline Aesculus hippocast. & + & + & - & - & - \\
\hline Populus tremula & + & - & - & + & - \\
\hline Prunus padus & + & - & + & - & - \\
\hline Quercus robur & + & + & - & - & - \\
\hline Sorbus aucuparia & + & + & - & - & - \\
\hline Host not indicated & 21 & 15 & 3 & 2 & - \\
\hline Specimens examined & 111 & 63 & 29 & 16 & 3 \\
\hline
\end{tabular}

Two well-defined variants of $P$. squamosus can be distinguished in Finland, which might best be considered ecotypes.

Almost half of the collections represent a "park ecotype". It has a Hemiboreal distribution and grows chiefly on large, living Ulmus, Fraxinus and Acer trees. It is a harmful parasite in old parks, and seems to invade trees via the scars of large, cut branches or cut halves of forked trunks. The fruit bodies are very large (up to $50 \mathrm{~cm}$ wide), often occur in clusters, and for decades can emerge fairly regularly each year in their host trees. The fungus is a harmful pathogen, as it causes extensive heart-rot, which finally hollows out the trunks of living trees. We have studied the decay pattern in cooperation with the Park Department of the City of Helsinki. In old Ulmus trees decay extends from ground level up to 5-10 metres; the decay column is very regular and inner parts soon become hollow. Around the central cavity a layer of very soft white-rot develops, surrounded by an even cylinder of harder rot. However, sound wood close to the treetrunk surface stays intact up to a very late stage and does not split like, for instance, the Acer wood surface when decayed by Rigidoporus populinus (Schum.: Fr.) Pouz. So the park trees inhabited by P. squamosus remain relatively safe even if the fungus has decayed them for decades.
The "park ecotype" is common chiefly in old downtown parks of Helsinki (Erkkilä \& Niemelä 1986) and Turku, and its distribution does not show any dependence on lakes, rivers or other waters. Erkkilä and Niemelä (1986) suggested that this "park ecotype" might be a neophyte in Finland, originating from Central Europe and being established only in parks in the north. Indeed, host trees are often exotic cultivars and, for instance, large Ulmus trees in nature seem to be free of this parasite (P. Uotila pers. comm.).

Over $50 \%$ of $P$. squamosus represent another group, which we call a "waterside ecotype". The collections originate from all over the country, especially the southwestern Lake District, northern coast of the Bothnian Sea, and northernmost Lapland. Its commonest hosts are bush-size Salix species, less often thin trunks of Betula; the host trees are indigenous. The fruit bodies are small, mostly $3-15 \mathrm{~cm}$ wide but can be up to $20 \mathrm{~cm}$ in diameter, and their details correspond to those of their larger, park-inhabiting counterpart. The "waterside ecotype", however, is a saprophyte of tall coppice stumps, both man-made and naturally broken ones. The pilei emerge singly on the wood exposed at the top of the stumps. This ecotype has a close affinity to water of some kind: river, brook, lakeside, or seaside. Its wide distribution and 


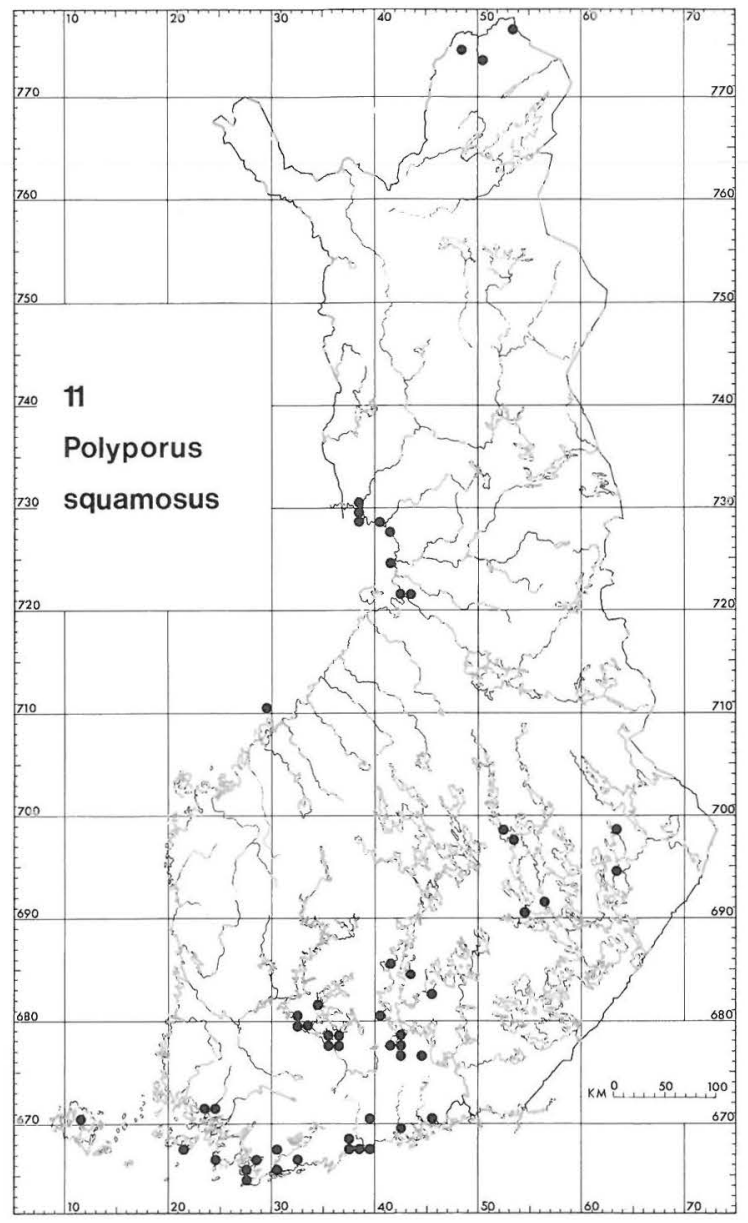

Fig. 11. Polyporus squamosus (Huds.: Fr.) Fr. in Finland.

ecology strongly suggest that it is an original, wellintegrated element of the Finnish flora, occupying a

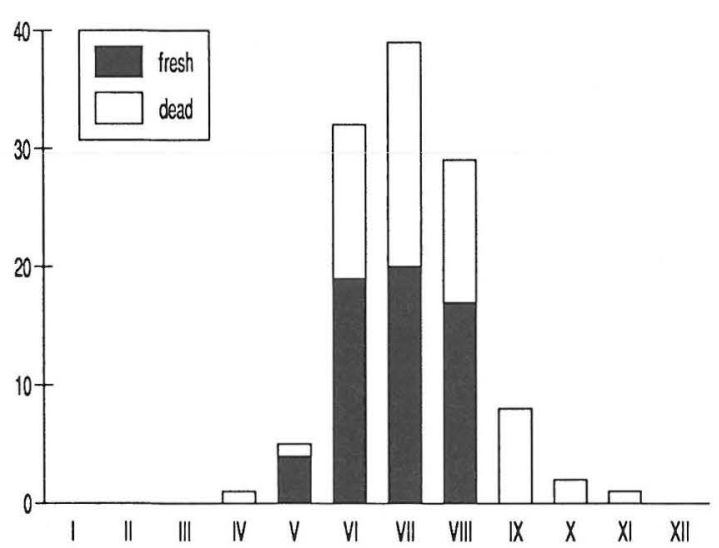

Fig. 12. Monthly distribution of collections of Polyporus squamosus (Huds.: Fr.) Fr. in Finland.

special ecological niche. In Norway the distribution reaches the northern coast of Scandinavia by the Arctic Ocean (Ryvarden 1978), but it has not been found along the extreme western coast (Ryvarden 1969).

Both the "park ecotype" in old city centres, and the "waterside ecotype" in natural thickets tend to form populations in which numerous trees are infected within a fairly restricted area. It appears that the species cannot establish stable, permanent occurrences in areas where suitable hosts are far apart. This might explain the species' absence from natural $\mathrm{Ul}$ mus trees, for example, because they mostly occur singly or in groups of a few individuals only.

$P$. squamosus fruits fairly early in the summer. The first caps usually appear in May, and the last fresh ones are to be seen in August. The cap primordia spread out to their final width within ca. ten days, shed their spores and die soon after; the sturdy pilei can remain in the trees long after their death.

\section{Polyporus tubaeformis Karst.}

\section{(See overleaf for host list)}

The woody plant genera Alnus, Betula and Salix serve as hosts for $P$. tubaeformis in three-quarters to four-fifths of the material. In South Finland the three genera are equally favoured by the fungus, but towards the north Salix soon decreases in importance, followed by Betula. Corylus, Populus, Sorbus, and, surprisingly, Rubus idaeus are occasional hosts.
Again, we regard the single record from a coniferous host (Picea abies) as suspicious.

$P$. tubaeformis is uncommon in general, but is collected regularly in suitable, rich sites in the Hemiboreal and Southern Boreal zones. It becomes rare in the Middle Boreal Finland, and there are only two records from the Northern Boreal zone. Although it 


\begin{tabular}{|c|c|c|c|c|c|}
\hline Host & Whole of Finland & A-U & EK-PK & KP-PP & $\mathrm{KiL}$ \\
\hline Alnus spp. & 28.8 & 18.2 & 30.4 & 66.7 & - \\
\hline - incana & 19.2 & & & & \\
\hline Betula spp. & 26.9 & 18.2 & 39.1 & + & + \\
\hline Salix spp. & 13.5 & 13.6 & 13.0 & + & - \\
\hline - caprea & 3.8 & & & & \\
\hline - myrsinifolia & 3.8 & & & & \\
\hline Corylus avellana & 9.6 & 22.7 & - & - & - \\
\hline Populus tremula & 5.8 & 9.0 & + & - & - \\
\hline Sorbus aucuparia & 5.8 & + & + & - & + \\
\hline Rubus idaeus & 3.8 & - & 8.7 & - & - \\
\hline Fraxinus excelsior & + & + & - & - & - \\
\hline Picea abies & + & + & - & - & - \\
\hline Pyrus communis & + & + & - & - & - \\
\hline Host not indicated & 55 & 13 & 37 & 11 & - \\
\hline Specimens examined & 113 & 35 & 60 & 17 & 1 \\
\hline
\end{tabular}

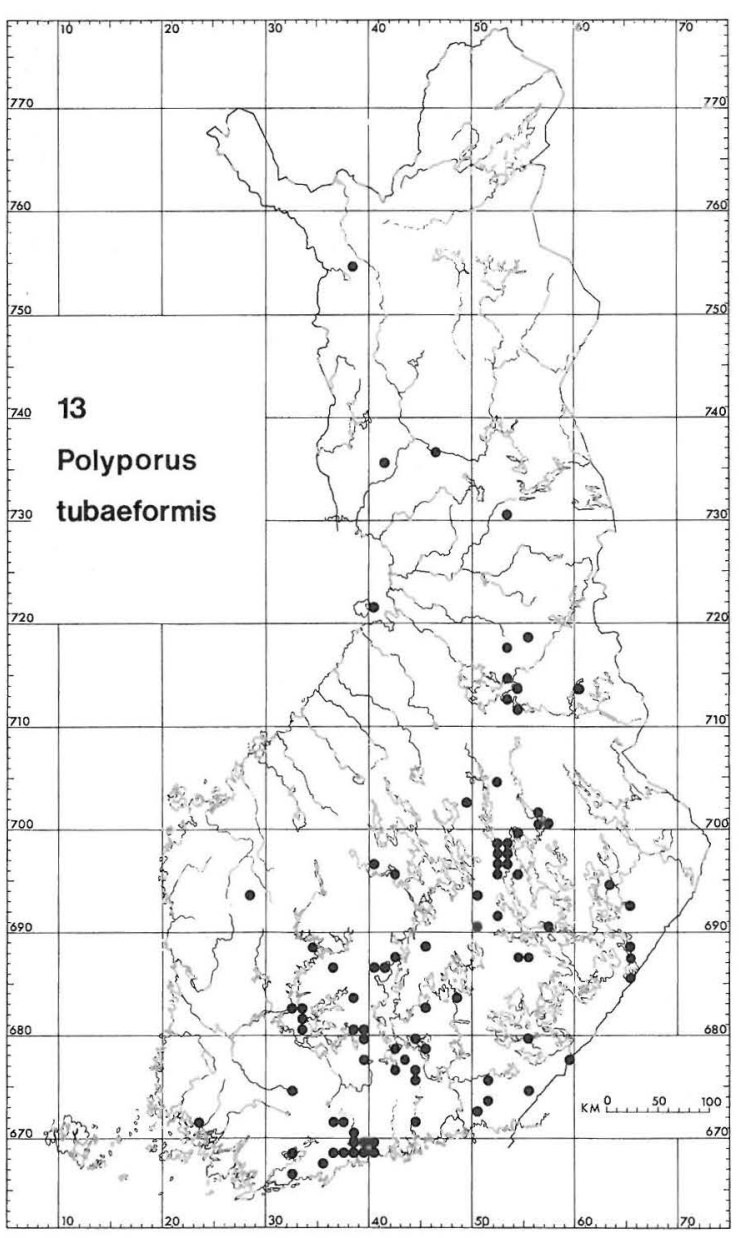

Fig. 13. Polyporus tubaeformis Karst. in Finland. is southern in Finland, the late Dr. Hermann Jahn (in litt. to T. Niemelä 15 Jan. 1987) considered this species - which he acknowledged without reservation, but had no time to publish - to be northern in Europe as a whole.

$P$. tubaeformis is a species of moist, rich grassherb forests which are little affected by humans and have plenty of decaying debris on the ground. In this respect, for instance, the contrast to $P$. melanopus is striking. The fruit bodies grow on fallen but exposed branches or even small twigs, and the fruit body size varies accordingly. Sometimes the fungus can be seen fruiting on strongly decayed stumps of alder, which are already at the stage of falling apart.

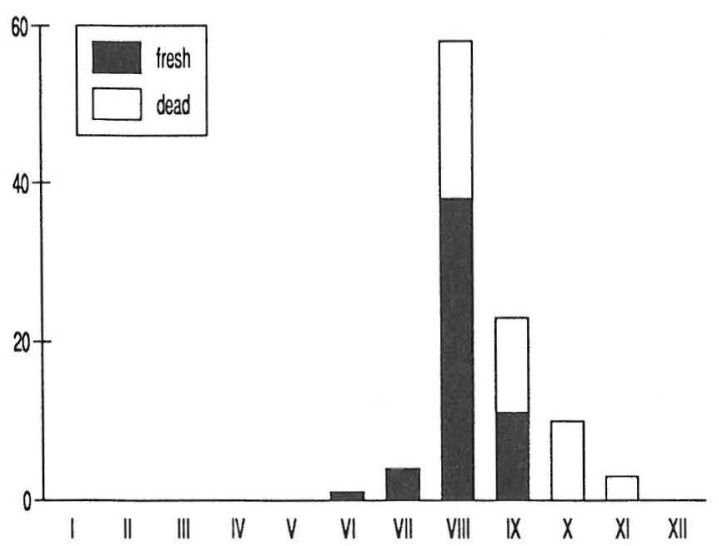

Fig. 14. Monthly distribution of collections of Polyporus tubaeformis Karst. in Finland. 
Fruiting starts in June and reaches its peak in August, decreasing rapidly thereafter. The pilei are much sturdier than those of $P$. melanopus, and dead, blackened caps are commonly found during late sum- mer and autumn, unlike those of $P$. melanopus. However, the pilei disintegrate in winter and cannot be recognized anymore next spring.
Polyporus umbellatus (Pers.: Fr.) Fr.

\begin{tabular}{|c|c|c|c|}
\hline & Whole of & A-U & EK-PK \\
\hline Specimens examined & 15 & 10 & 5 \\
\hline
\end{tabular}

The distribution of $P$. umbellatus is Hemiboreal to Southern Boreal in Finland, and the species is very rare, being classified as threatened, vulnerable (Rassi et al. 1986). It is considered vulnerable in Sweden (Ingelög et al. 1984) and Denmark (Knudsen \& Vesterholt 1990) as well. The fruit bodies wither very soon, which makes it difficult to estimate the constancy of the species in its isolated localities. However, H. Kotiranta has followed the emergence in a single locality (685:43, Fig. 15), and fruit bodies have been found almost every year from 1977 to 1990. Fruiting is early, mostly in July.

The fruit body aggregates of $P$. umbellatus arise from perennial, tuberous sclerotia, which lie just below the loose litter layer on the ground. Some observations made at the site (685:43) suggest that badgers (Meles meles) dig up the fleshy bodies and eat them.

In the literature $P$. umbellatus is mostly considered to have an affinity to oak (e.g., Kotlaba 1984), and two South Finnish observations (667:32, 668:24) agree with this. However, most records in Finland exclude this connection altogether. The ecology cannot be easily described. Most finds in the country derive from mixed forests, some of them rich grassherb sites, but some also from a transitional zone

Acknowledgements. The curators of various herbaria are thanked for arranging loans, and the activities of numerous collectors have contributed greatly to the completion of the maps. Special thanks are due to Pirkko Askola, Veli Haikonen, Markku Kirsi, Ilkka Kytövuori, Reijo Penttilä, Reima Saarenoksa, Unto Söderholm, and P.G. Wikstrom. The English of this paper was revised by Mrs Anna A. Damström, M.A.

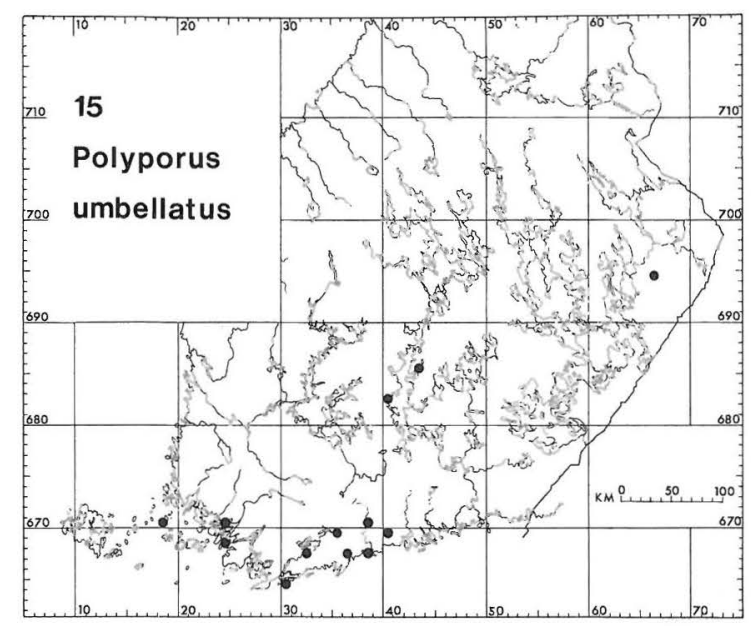

Fig. 15 Polyporus umbellatus (Pers.: Fr.) Fr. in Finland.

adjoining Sphagnum bogs, overshadowed by poorly growing pines. One collection was made from a stump of spruce.

The species has been recorded earlier from Finland by Niemelä (1978), Kotiranta and Niemelä (1981), and Erkkilä and Niemelä (1986). In the present map, one locality $(669: 40)$ is based on a good photograph (c/o P.G. Wikström) and another (667:38) on a personal communication (R. Saarenoksa).

\section{References}

Dunger, I. 1987: Kartierung der Porlinge (porige Polyporales und Poriales) der Oberlausitz 1. Verbreitung und Okologie der Arten. - Abh. Ber. Naturkundemus. Görlitz 60(11): 1-160.

Elborne, S.A. \& Knudsen, H. 1990: Larger fungi associated with Betula pubescens in Greenland. - Medd. Grönland, 
Biosci. 33:77-80.

Eriksson, J. \& Strid, А. 1969: Studies in the Aphyllophorales (Basidiomycetes) of northern Finland. - Rep. Kevo Subarctic Res. Sta. 4:112-158.

Erkkilä, R. \& Niemelä, T. 1986: Polypores in the parks and forests of the City of Helsinki. - Karstenia 26:1-40.

Esser, K. \& Hoffmann, P. 1977: Genetic basis for speciation in higher Basidiomycetes with special reference to the genus Polyporus. In: Clémençon, H. (ed.), The species concept in Hymenomycetes (Bibl. Mycol. 61). — Pp. 189-214. J. Cramer, Vaduz.

Greuter, W. et al. 1988: International Code of Botanical Nomenclature. - 328 pp. Koeltz Scientific Books, Köningstein.

Hagström, E. 1971: Polyporus melanopus and P. picipes, a taxonomic study. - Göteborgs Svampklubbs Arskrift 1971 (Windahlia 1): 28-43.

Haligrímsson, H. 1966: Íslenskir sáldsveppir, Polyporaceae. - Ársrit Skógræktarfélags Íslands 1966:12-16.

Ingelög, T., Thor, T. \& Gustafsson, L. 1984: Floravård i skogsbruket 2. Artdel. - 408 pp. Skogsstyrelsen, Jönköping.

Jahn, H. 1979: Pilze die an Holz wachsen. - 268 pp. Busse, Herford.

Jülich, W. 1984: Die Nichtblätterpilze, Gallertpilze und Bauchpilze. - In: Gams, H., Kleine Kryptogamenflora IIb/1, Basidiomyceten 1. - 626 pp. Gustav Fischer Verlag, Stuttgart \& New York.

Knudsen, H. 1982: Ekskursioner. Den 18-20/9 1981. Svampe 6:112-113.

Knudsen, H. \& Vesterholt, J. 1990: Truede storsvampe i Danmark, en rödliste. - $64 \mathrm{pp}$. Foreningen til Svampekundskabens Fremme \& Skov- og Naturstyrelsen, Söborg.

Kotiranta, H. \& Niemelä, T. 1981: Composition of the polypore communities of four forst areas in southem Central Finland. - Karstenia 21:31-48.

Kotlaba, F. 1984: Zeměpisné rozšrínení a ekologie chorosù (Polyporales s.1.) v Československu. - 194 pp., 123 maps. Academia, Praha.

Krieglsteiner, G.J. \& Krieglsteiner, L.G. 1989: Die Pilze Ostund Nord-Württembergs 1. Nichtblătterpilze s.1. - Beitr. Pilze Mitteleuropas 4:1-423.

Niemelä, T. 1978: The occurrence of some rare pore fungi in
Finland. - Ann. Bot. Fennici 15:1-6.

Niemelä, T. 1982: Polypore survey of Finland 1. Introduction. - Karstenia 22:21-26.

Niemelä, T. 1985: Mycoflora of Poste-de-la-Baleine, northern Québec. Polyporales and the Hymenochaetales. - Naturaliste Canadien 112:445-472.

Niemelä, T. \& Kotiranta, H. 1982: Polypore survey of Finland 2. The genus Phellinus. - Karstenia 22:27-42.

Niemelä, T. \& Kotiranta, H. 1983: Polypore survey of Finland 3. The genera Coltricia, Inonotopsis, Inonotus and Onnia. - Karstenia 23:15-25.

Niemelä, T. \& Kotiranta, H. 1986: Polypore survey of Finland 4. Phaeolus, Fistulina, Ganoderma and Ischnoderma. - Karstenia 26:57-64.

Plank, S. 1978: Ökologie und Verbreitung holzabbauender Pilze im Burgenland. - Wiss. Arb. Burgenland 61:1-207.

Rassi, P. et al. 1986: Uhanalaisten eläinten ja kasvien suojelutoimikunnan mietintő 3. Suomen uhanalaiset kasvit. Komiteamietintő 1985:43. - 431 pp. Ympäristöministeriő, Helsinki.

Rassi, P. \& Väisänen, R. 1987: Threatened animals and plants in Finland. English summary of the report of the Committee for the Conservation of Threatened Animals and Plants in Finland. - 82 pp. Ympäristöministeriö, Helsinki.

Ryman, S. \& Holmåsen, I. 1984: Svampar, en fălthandbok. 718 pp. Interpublishing, Stockholm.

Ryvarden, L. 1969: The genus Polyporus s.str. in Norway. Nytt Mag. Bot. 16:151-157.

Ryvarden, L. 1971: Studies in the Aphyllophorales of Finnmark, northern Norway. - Rep. Kevo Subarctic Res. Sta. $8: 148-154$.

Ryvarden, L. 1978: The Polyporaceae of North Europe 2. Inonotus to Tyromyces. - Pp. 215-507. Fungiflora, Oslo.

Strid, A. 1975: Wood-inhabiting fungi in alder forests in North-Central Scandinavia 1. Aphyllophorales (Basidiomycetes). Taxonomy, ecology and distribution. - Wahlenbergia 1:1-237.

Thorn, G., Kotiranta, H. \& Niemelä, T. 1990: Polyporus pseudobetulinus comb.nov., new records in Europe and North America. - Mycologia 82:582-594.

Received on 29 November 1990 